\title{
The dynamic change of pore structure for low-rank coal under refined upgrading pretreatment temperatures
}

\author{
Teng $\mathrm{Li}^{1,2,3} \cdot$ Cai-Fang $\mathrm{Wu}^{4} \cdot \mathrm{Zi}-$ Wei Wang ${ }^{4}$
}

Received: 27 August 2020 / Accepted: 13 October 2020 / Published online: 3 December 2020

(c) The Author(s) 2020

\begin{abstract}
Pore structure characteristics are significant factor in the evaluation of the physical characteristics of low-rank coal. In this study, three low-rank coal samples were collected from the Xishanyao Formation, Santanghu Basin, and low-temperature liquid-nitrogen adsorption ( $\left.\mathrm{LP}-\mathrm{N}_{2} \mathrm{~A}\right)$ measurements were taken under various pretreatment temperatures. Owing to the continuous loss of water and volatile matter in low-rank coal, the total pore volume assumes a three-step profile with knee temperatures of $150{ }^{\circ} \mathrm{C}$ and $240{ }^{\circ} \mathrm{C}$. However, the ash in the coal can protect the coal skeleton. Pore collapse mainly occurs for mesopores with aperture smaller than $20 \mathrm{~nm}$. Mesopores with apertures smaller than $5 \mathrm{~nm}$ exhibit a continuous decrease in pore volume, whereas the pore volume of mesopores with apertures ranging from 5 to $10 \mathrm{~nm}$ increases at lower pretreatment temperatures $\left(<150{ }^{\circ} \mathrm{C}\right)$ followed by a faint decrease. As for mesopores with apertures larger than $10 \mathrm{~nm}$, the pore volume increases significantly when the pretreatment temperature reaches $300{ }^{\circ} \mathrm{C}$. The pore structure of low-rank coal features a significant heating effect, the pretreatment temperature should not exceed $150{ }^{\circ} \mathrm{C}$ when the $\mathrm{LP}-\mathrm{N}_{2} \mathrm{~A}$ is used to evaluate the pore structure of low-rank coal to effectively evaluate the reservoir characteristics of low-rank coal.
\end{abstract}

Keywords Low-rank coal · Low-temperature liquid-nitrogen adsorption · Pore structure · Refined upgrading temperatures · Heating effect

\section{Introduction}

Lignite and long-flame coal are typical types of low-rank coal, and their extraction is well developed in China. For example, the Erlian Basin, Hailer Basin, Hunchun Basin and Tiefa Basin in northeastern China; Turpan-Hami Basin, Junggar Basin, Yili Basin, Tarim Basin, Qaidam Basin and

Edited by Jie Hao and Chun-Yan Tang.

Teng Li

liteng2052@163.com

1 College of Petroleum Engineering, Xi' an Shiyou University, Xi' an 710065, Shaanxi, China

2 Shandong Key Laboratory of Depositional Mineralization and Sedimentary Mineral, Shandong University of Science and Technology, Qingdao 266590, Shandong, China

3 Shaanxi Key Laboratory of Advanced Stimulation Technology for Oil and Gas Reservoirs, Xi' an Shiyou University, Xi' an 710065, Shaanxi, China

4 School of Resources and Geosciences, China University of Mining and Technology, Xuzhou 221008, Jiangsu, China
Santanghu Basin in northwestern China; Ordos Basin in central China; and Zhaotong Basin in southwestern China are all basins that contain not only abundant low-rank coal resources (Jian et al. 2015; Xin et al. 2019), but also large amounts of low-rank coalbed methane. The potential of lowrank coalbed methane resource in China is approximately $1.7 \times 10^{13} \mathrm{~m}^{3}$, which contributes almost $40 \%$ of the total Chinese coalbed methane resources (Wang et al. 2017). There has been commercial development of high-rank coalbed methane in Qinshui Basin, whereas the development of low-rank coalbed methane in China is still at the preliminary stage. Currently, the research of low-rank coalbed methane in China is mainly focused on accumulation (Xu et al. 2012; Fu et al. 2016; Li et al. 2018).

The pore structure is one of the key factors that can significantly influence the adsorption, desorption, diffusion and seepage of coalbed methane in coal, and detailed research on the pore structure of coal can favor the development of low-rank coalbed methane. The pore structure characteristics of low-rank coal are different from those of medium- and high-rank coal (Jian et al. 2015). Low-rank coal exhibits high porosity; however, with an increase in the degree of 
coalification, the porosity of low-rank coal continuously decreases (Wang et al. 2018; Zhang et al. 2018). Jian et al. (2015) collected 42 low-rank coal samples, and the dynamic changes of the pore volume and specific surface area of the micropores $(<10 \mathrm{~nm})$, transition pores $(10-100 \mathrm{~nm})$, mesopores $(100-1000 \mathrm{~nm})$ and macropores $(>1000 \mathrm{~nm})$ were studied in detail with increased coalification. For lowrank coal with the maximum vitrinite reflectance $(R o, \max )$ ranging from $0.24 \%$ to $0.65 \%$, the pore volume, pore specific surface area and porosity decrease first and then increase with increased thermal maturity, reaching minimum at $R_{0}, \max =0.5 \%$. This is mainly due to compaction and water loss during the deposition process (Jian et al. 2015). The pore aperture in low-rank coal is typically below $10 \mathrm{~nm}$ (Cai et al. 2013), which favors the adsorption of methane. Mesopores with apertures ranging from 100 to $1000 \mathrm{~nm}$ are largely undeveloped, and macropores in low-rank coal are mainly plant tissue pores (Fu et al. 2017). However, the results from Jian et al. (2015) showed that pores with apertures from 10 to $100 \mathrm{~nm}$ are the most developed in low-rank coal. This difference in the results may be due to regional differences. Lignite and long-flame coal are developed in eastern Junggar Basin, whereby the inertinite content, pore volume, pore connectivity and pore specific surface area of the lignite are superior to that in long-flame coal (with ten coal samples) (Tao et al. 2018). For long-flame coal, the pore specific surface area is mainly provided by the micropores $(<10 \mathrm{~nm})$, particularly the pores with apertures from 2 to $3 \mathrm{~nm}$. However, the pore specific surface area of the lignite is mainly derived from the transition pores $(10-100 \mathrm{~nm})$ (Tao et al. 2018). The micropore volume $(<10 \mathrm{~nm})$ contributes dominantly to the total pore volume of low-rank coal in Ordos Basin (with 12 coal samples), and those for the mesopores (10-100 $\mathrm{nm})$ and macropores $(>100 \mathrm{~nm})$ are approximately equal; in fact, the heterogeneity of the pore size distribution in the various types of low-rank coal is strong (Xu et al. 2012). The distribution of the pores in the various macrolithotypes is also varied for different types of low-rank coal; macropores in the dull coal are few, whereas the pore structure of bright coal is complex (Zhao et al. 2019). The structure of the pores in inertinite is typically single with larger pore aperture, which favors the migration of methane, whereas the pores in vitrinite are complex with smaller pore apertures that favor the adsorption of methane (Sakurovs et al. 2012; Liu et al. 2015). Minerals may be filled into the plant tissue pores in low-rank coal, which would also influence the pore structure (Tao et al. 2018). It can be concluded that the coal rank, mineral content and types of the macerals in low-rank coal would significantly influence its pore structure (Wang et al. 2018).

Various methods can be used to investigate the pore structure of low-rank coal, such as scanning electron microscopy (SEM), low-temperature liquid-nitrogen adsorption $\left(\right.$ LP- $\left.\mathrm{N}_{2} \mathrm{~A}\right)$, high-pressure mercury intrusion (MIP), constant-rate mercury intrusion (CR-MI) and low-field nuclear magnetic resonance (LF-NMR) (Jian et al. 2015; Pan et al. 2019; Xin et al. 2019). LP- $\mathrm{N}_{2} \mathrm{~A}$ is mostly used to measure the pore structure of lowrank coal. Before the implementation of $\mathrm{LP}-\mathrm{N}_{2} \mathrm{~A}$, the coal sample is pretreated below $300{ }^{\circ} \mathrm{C}$ to avoid adsorbed impurities on the coal. Under the measurement pretreatment temperature, with the loss of moisture in the coal, the porosity, meso- and macropore specific surface areas decrease (Deevi and Suuberg 1987; Salmas et al. 2001; Sakurovs et al. 2016). The moisture in macropores with pore apertures larger than $120 \mathrm{~nm}$ would be lost first, which would lead to a decreased porosity of approximately $43 \%$ (Evans 1973). When the moisture in the pore aperture ranging from 4 to $120 \mathrm{~nm}$ tends to be lost, pore collapse occurs, especially for pores with apertures ranging from 2 to $18 \mathrm{~nm}$ (Deevi and Suuberg 1987). Furthermore, low-rank coal typically features high volatile content (Tao et al. 2018); thus, a higher pretreatment temperature may lead to the volatilization of the volatile matter from the low-rank coal. Yin et al. (2019) performed pyrolysis measurements on lignite from Erlian Basin under temperatures of 600, 750 and $900{ }^{\circ} \mathrm{C}$ and found that a large amount of volatiles separate out under those conditions. In addition, the pores collapse under high pyrolysis temperatures. However, it should be noted that the pyrolysis temperature is much higher than that in the pretreatment of $\mathrm{LP}-\mathrm{N}_{2} \mathrm{~A}$ process. Thus, the issue arises whether moisture and volatiles can be separated out under the lower pretreatment temperature before the implementation of LP- $\mathrm{N}_{2} \mathrm{~A}$. This is important because the pore structure of lowrank coal under various pretreatment temperatures would be different with the continuous decrease in moisture and volatiles, which would finally determine the true pore structure of low-rank coal.

Previous studies on the pore structure of low-rank coal were mainly based on coal samples with various thermal maturities. However, the heterogeneity of low-rank coal is strong; thus, there would be different indications as to its pore structure (Cai et al. 2013; Jian et al. 2015; Tao et al. 2018). There has been very little attention paid to the dynamic change in the pore structure underrefined upgrading pretreatment temperatures with $\mathrm{LP}-\mathrm{N}_{2} \mathrm{~A}$. In this study, low-rank coal samples were collected from Santanghu Basin in Xinjiang, China, and the pore structure of low-rank coal samples with LP- $\mathrm{N}_{2} \mathrm{~A}$ under refined upgrading pretreatment temperatures was studied.

\section{Samples and measurement procedures}

\subsection{Samples}

Low-rank coal samples were collected from the Middle Jurassic Xishanyao Formation (XSY) in Santanghu Basin, 
Xinjiang, northwestern China. The Xishanyao Formation is a transition facies deposition from shore-shallow-lake facies to lacustrine-delta facies, and the coal bearing formation was mainly developed at the lacustrine-swamp facies and the delta-front facies. The average thickness of the Xishanyao Formation was $476.59 \mathrm{~m}$ with a maximum coal seam of 22 layers, and the cumulative thickness of the coal can reach $100 \mathrm{~m}$.

In Xishanyao Formation, three coal samples were collected from drilling cores with a diameter of $25 \mathrm{~mm}$, and the length of the cores ranged from 5 to $8 \mathrm{~cm}$. Low-rank coal can be weathered easily. The moment the fresh coal samples were acquired, they were immediately packaged with valve bags and sent to the laboratory for measurements.

\subsection{Measurements}

\subsubsection{Measurements of the basic properties of the coal samples}

Measurements of the basic properties of the coal samples included proximate analysis, maceral identification, mean Ro and SEM. The proximate analysis of the coal samples was carried out following the Chinese national standard GB/T 212-2008. According to the Chinese national standards GB/T 8899-2013 and GB/T 6948-2008, the macerals were inentified, and Ro of the coal samples was measured. SEM of the coal samples was performed according to the Chinese national standard GB/T 17722-1999 with the MAIA3 model 2016 (LM) ultrahigh-resolution field-emission scanning electron microscope.

\subsubsection{LP- $\mathrm{N}_{2} \mathrm{~A}$ measurements of the low-rank coal samples}

Mesopores and macropores are dominant in low-rank coal (Nugroho et al. 2000; Mahidin et al. 2003; Cai et al. 2013), and $\mathrm{LP}-\mathrm{N}_{2} \mathrm{~A}$ can accurately reveal the structure of the pores with apertures larger than $0.7 \mathrm{~nm}$ accurately (Lee et al. 2006; Thommes and Cychosz 2014; Li et al. 2019). Then, the pore structure of the low-rank coal samples was analyzed through LP- $\mathrm{N}_{2} \mathrm{~A}$ measurements with the TriStar II specific surface area instrument, and the determination of the specific surface area of solids by gas adsorption using the BET method was taken as the reference. Before the LP-N $\mathrm{N}_{2} \mathrm{~A}$ measurements are taken, the coal samples should be dried to discharge any available moisture and adsorbed gas from the surface of the coal; this procedure should be completed at a particular temperature. In this study, the pore structure differences of lowrank coal were studied under refined upgrading pretreatment temperatures, where the pretreatment temperatures here refer to the various drying temperatures. There were seven various pretreatment temperatures set from 120 to $300{ }^{\circ} \mathrm{C}$ at intervals of $30^{\circ} \mathrm{C}$, and the concrete procedures were as follows:

First, the sample tube was washed with alcohol to clean the probable impurities on the surface, followed by drying with the Micromeritics Vac Prep 061 Sample Degas System for $3 \mathrm{~h}$ at $150{ }^{\circ} \mathrm{C}$ and balancing. Next, a certain amount of the coal samples was added into the sample tube. Then, the sample was dried with Micromeritics Vac Prep 061 Sample Degas System again at the pretreatment temperature of $120{ }^{\circ} \mathrm{C}$; when the vacuum degree reached to 0.05 mbar, it was thought to be dried completely. The sample tube with sample was balanced again to calculate the mass of the sample. Finally, the LP-N $2 \mathrm{~A}$ measurement of the low-rank coal sample at a pretreatment temperature of $120{ }^{\circ} \mathrm{C}$ was taken at $-196{ }^{\circ} \mathrm{C}$ with a maximum relative pressure of approximately one. When the LP-N ${ }_{2} \mathrm{~A}$ measurement was completed, the coal sample was treated again at various pretreatment temperatures 150, 180, 210, 240, 270 and $300{ }^{\circ} \mathrm{C}$. After the various pretreatment temperatures, the LP- $\mathrm{N}_{2} \mathrm{~A}$ measurements of the coal samples were taken.

To reduce the deviation, the vacuum degree should reach 0.05 mbar under the various pretreatment temperatures. In addition, three coal samples were utilized at the same time to avoid abnormal results arising from the testing of a single sample. The adsorption curve and desorption curve can be acquired from the LP- $\mathrm{N}_{2} \mathrm{~A}$ measurements, whereby the adsorption curve is typically used to reveal the pore structure of the coal (Groen et al. 2003; Thommes and Cychosz 2014). The Barrett-Joyner-Halenda model was used to calculate the pore volume and pore size distribution, and the Brunauer-Emmett-Teller model was utilized to acquire the specific surface area.

\section{Results and discussion}

\subsection{Maceral and proximate analysis of the coal samples}

The $R_{\mathrm{o}}$ of the three coal samples ranges from $0.352 \%$ to $0.374 \%$ (Table 1), indicating that the coal is lignite. Vitrinite (with a range of $68.67 \%$ to $68.72 \%$ ) is dominant in the low-rank coal samples, followed by inertinite (with a range of $22.95 \%$ to $24.67 \%$ ), and exinite is the least abundant (Table 1). The moisture content on an air-dried basis ranges from $14.48 \%$ to $17.12 \%$, ash yield on a dry basis varies from $12.74 \%$ to $16.28 \%$, and the volatile content on a dry, ash-free basis ranges from $41.24 \%$ to $41.56 \%$ (Table 1), which indicates that low-rank coal in Xishanyao Formation features medium and high moisture content, medium and low ash yield and high volatile content. 
Table 1 Results of the proximate and maceral analyses and the $R_{\mathrm{o}}$ of the coal samples

\begin{tabular}{|c|c|c|c|c|c|c|c|c|}
\hline \multirow[t]{2}{*}{ Sample } & \multirow[t]{2}{*}{ Formation } & \multirow[t]{2}{*}{$R_{\mathrm{o}}, \%$} & \multicolumn{3}{|c|}{ Coal composition, $\%$} & \multicolumn{3}{|c|}{ Proximate analysis, $\%$} \\
\hline & & & Vitrinite & Inertinite & Exinite & $M_{\mathrm{ad}}$ & $A_{\mathrm{d}}$ & $V_{\text {daf }}$ \\
\hline XSY-1 & $\mathrm{J}_{2} \mathrm{x}$ & $0.352 *$ & 68.67 & 24.67 & 6.66 & 15.94 & 12.74 & 41.33 \\
\hline XSY-2 & $\mathrm{J}_{2} \mathrm{X}$ & 0.371 & 68.58 & 23.41 & 8.01 & 14.48 & 16.28 & 41.24 \\
\hline XSY-3 & $\mathrm{J}_{2} \mathrm{x}$ & $0.374 *$ & 68.72 & 22.95 & 8.33 & 17.12 & 15.12 & 41.56 \\
\hline
\end{tabular}

*Quantity of the coal sample is less, the result is suggested for reference; ad, air-dried basis; d, free basis; daf, dry ash free basis

\subsection{Change in the pore structure of XSY coal samples under various pretreatment temperatures}

\subsubsection{Change in LP- $\mathrm{N}_{2} A$ curves}

There are six types of LP- $\mathrm{N}_{2} \mathrm{~A}$ curves and four types of hysteresis loops for porous media (Sing et al. 1985). The LP- $\mathrm{N}_{2} \mathrm{~A}$ curves of the XSY coal samples are present as type IV; meanwhile, the shapes of the adsorption/desorption curves of the XSY coal samples are different under the various pretreatment temperatures, and can be classified as $\mathrm{H}_{1}$ type or $\mathrm{H}_{2}$ type, according to the IUPAC classification method (Fig. 1). The $\mathrm{H}_{2}$ type hysteresis loop appears when the pretreatment temperature of the coal samples is below $240{ }^{\circ} \mathrm{C}$, and the $\mathrm{H}_{1}$ type hysteresis loop emerges with higher pretreatment temperatures of $270{ }^{\circ} \mathrm{C}$ and $300{ }^{\circ} \mathrm{C}$.

The dynamic change in the adsorption curves under various pretreatment temperatures is similar. Under a lower relative pressure $(<0.8)$, the increase in the $\mathrm{N}_{2}$ adsorption quantity is slow. When the relative pressure reaches $0.8-0.9$, it shows a quick increase, and the $\mathrm{N}_{2}$ adsorption quantity features a sharp and rapid increase when the relative pressure exceeds 0.9 , reaching the maximum $\mathrm{N}_{2}$ adsorption quantity rapidly (Fig. 1).

The difference between the $\mathrm{H}_{2}$ type and $\mathrm{H}_{1}$ type hysteresis loop is the size. For coal with an $\mathrm{H}_{2}$ type hysteresis loop, which corresponds to lower pretreatment temperatures ranging from 120 to $240{ }^{\circ} \mathrm{C}$, the desorption curve decreases rapidly when the relative pressure decreases to 0.9 , and the narrow hysteresis loop indicates parallel plate pores with all sides open. With the continuous decrease in the relative pressure, desorption and adsorption curves are not reversible and are nearly parallel, with a relative pressure range of 0.5 to 0.8 . The size of the hysteresis loop becomes larger, indicating cylindrical or prismatic pores with two sides open, while there are some fine pore throat structures in these pores, suggesting complex pore system. When the relative pressure decreases to 0.5 , there is a sharp inflection point on desorption curve, which is a reflection of fine-neck pores and ink-bottle pores. When the relative pressure decreases sequentially, the hysteresis loop tends to be closed, and the morphology of the pores is impermeable with one side almost closed. In fact, the hysteresis loop is not completely closed at the lower relative pressure, which is common for a porous medium (Burgess et al. 1989; Chen et al. 2018). Burgess et al. (1989) reasoned that the unclosed hysteresis loop is related to the size difference between the adsorbent pore and adsorbate. With approximately equal diameters for the pore and adsorbate, the hysteresis loop would not be closed. The $\mathrm{H}_{1}$ type hysteresis loop emerges when the coal samples are used with higher pretreatment temperatures $\left(270{ }^{\circ} \mathrm{C}\right.$ and $300{ }^{\circ} \mathrm{C}$ ), and it is similar to the $\mathrm{H}_{2}$ type hysteresis loop. The hysteresis loop of the $\mathrm{H}_{1}$ type is narrow for a relative pressure range of 0.4 to 1 , and there is no sharp inflection point at a relative pressure of 0.5 , indicating parallel plate pores with all sides open and cylindrical pores with two sides open in the coal. For a relative pressure below 0.4 , the hysteresis loop is closed, signifying the coniform pores and sphenoid pores with one side closed (Song et al. 2017).

\subsubsection{Change in total pore volume and specific surface area}

The dynamic change in the total pore volume (TPV) of the XSY coal samples is presented as a three-step profile. The TPV reaches the maximum when the pretreatment temperature is $150^{\circ} \mathrm{C}$. Afterward, it decreases with increasing pretreatment temperatures. The TPV of XSY-1 and XSY-2 coal samples reach a minimum at the pretreatment temperature of $240{ }^{\circ} \mathrm{C}$, whereas that for the XSY-3 coal samples is $270{ }^{\circ} \mathrm{C}$. Finally, there is a weak increase for the TPV of the XSY coal samples (Fig. 2). The dynamic changes of TPV for the three low-rank coal samples are various, indicating the strong heterogeneity of the coal. With regard to the total specific surface area (TSSA), it decreases linearly at pretreatment temperatures below $240{ }^{\circ} \mathrm{C}$ (Fig. 2). When the pretreatment temperatures exceed $240{ }^{\circ} \mathrm{C}$, the decrease in TSSA is slow.

\subsubsection{Change in cumulative pore volume and specific surface area}

The cumulative pore volume (CPV) increases slowly for pores with apertures below $10 \mathrm{~nm}$, and it increases linearly for pore apertures larger than $10 \mathrm{~nm}$ (Fig. 3). The 

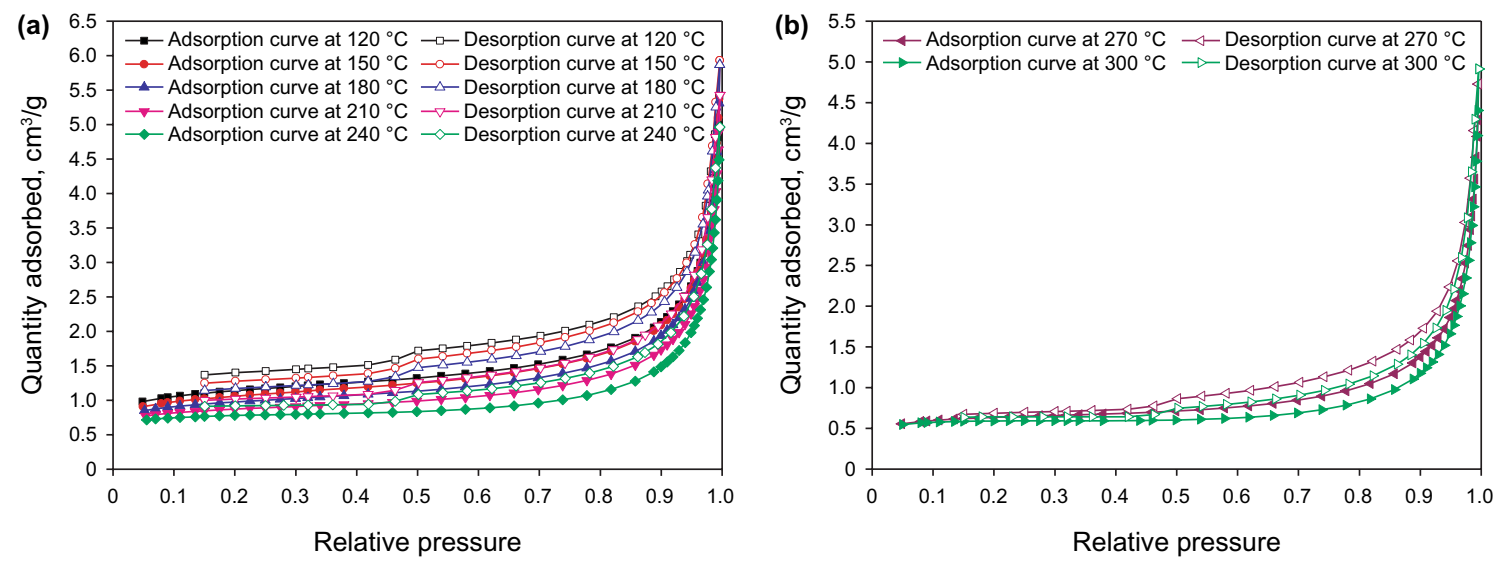

XSY-1 coal sample
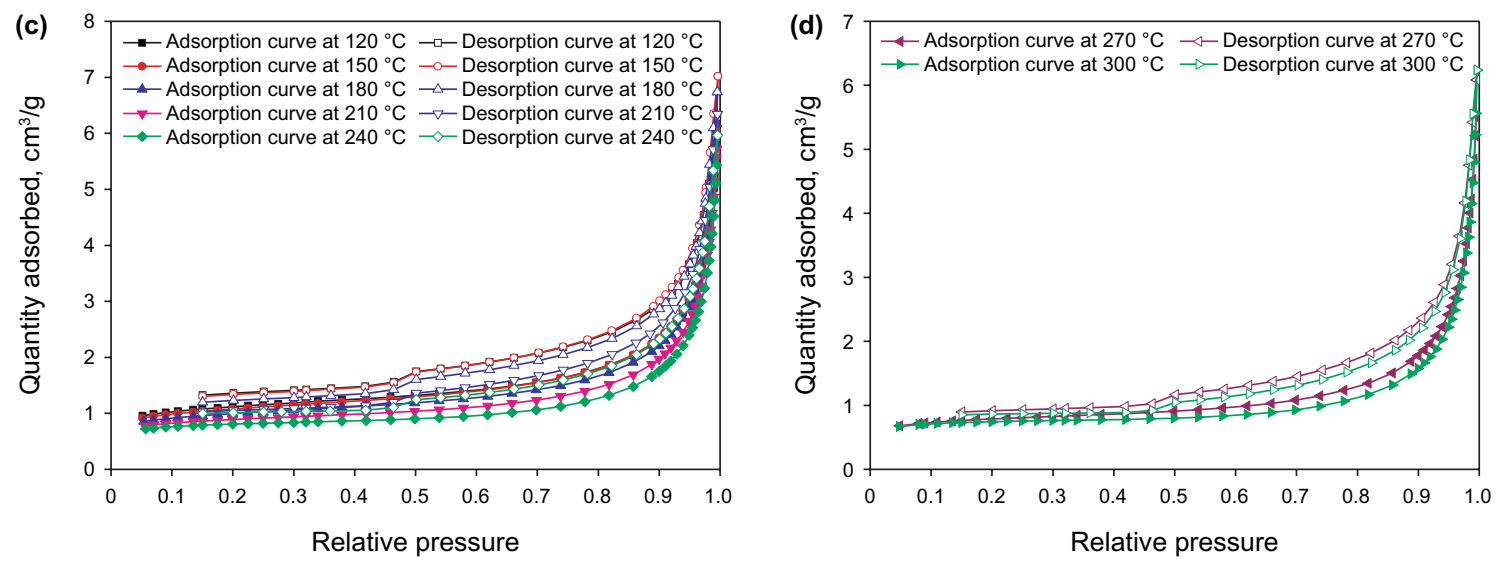

XSY-2 coal sample
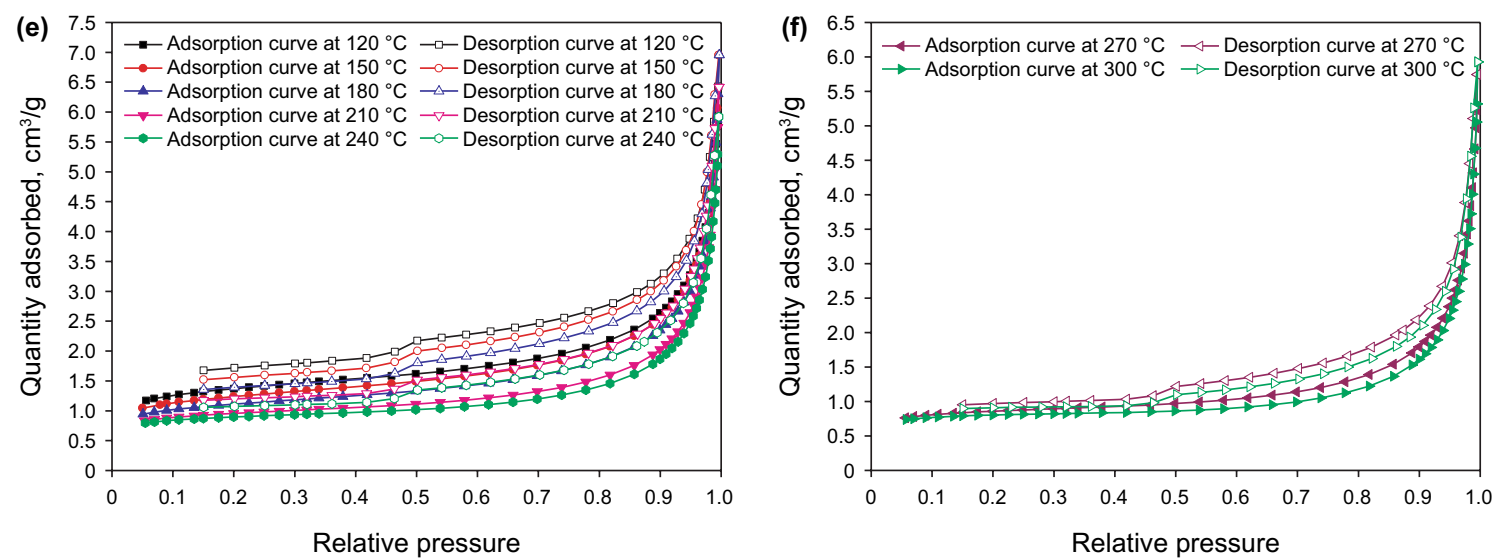

XSY-3 coal sample

Fig. 1 LP-N ${ }_{2} \mathrm{~A}$ curves of the XSY coal samples

increase in the cumulative specific surface area (CSSA) varies with different pretreatment temperatures. The rapid increase in the CSSA is almost the same for coal samples under lower pretreatment temperatures $\left(<180^{\circ} \mathrm{C}\right)$; then, it increases to the maximum and remains stable in the case of macropores.

\subsubsection{Change in incremental pore volume and specific surface area}

XSY coal samples present a wide range of pores, and the pores can be divided into two sections at the aperture of $5 \mathrm{~nm}$. The PV of the XSY coal samples are mainly provided 

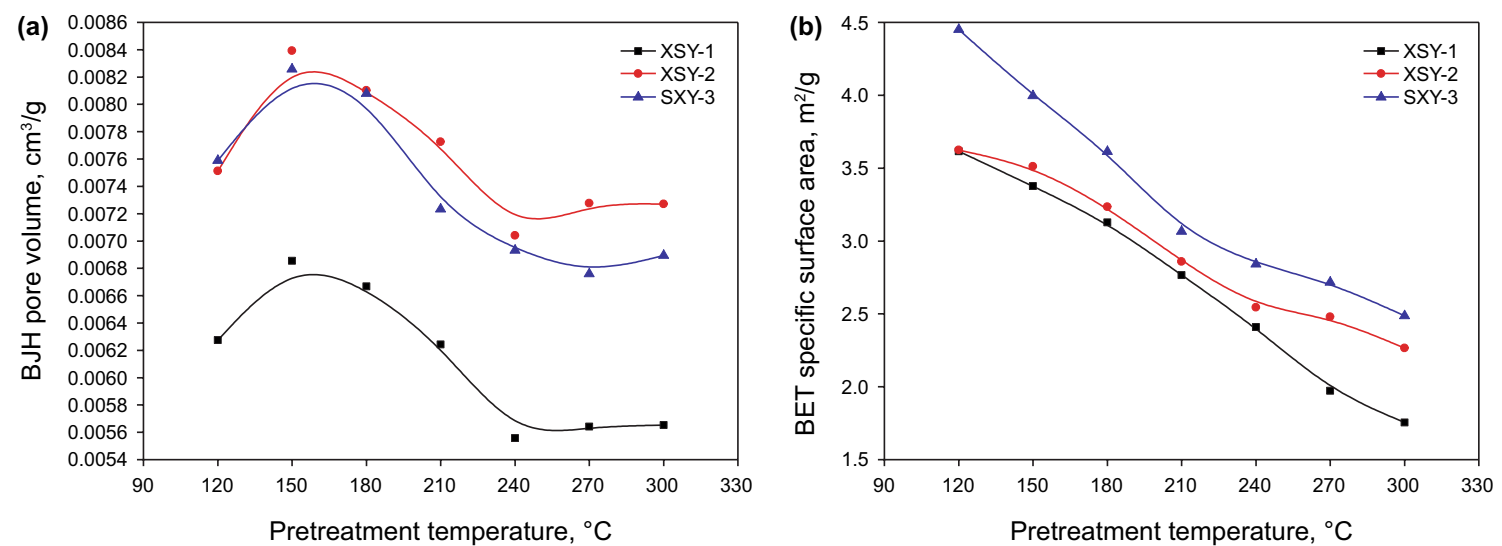

Fig. 2 Dynamic change in TPV and TSSA of the three coal samples under various pretreatment temperatures

by the pores with apertures below $20 \mathrm{~nm}$ (Fig. 4). With an increase in the pretreatment temperatures, the PV and SSA of the pores with apertures smaller than $20 \mathrm{~nm}$ decrease continuously, whereas that for pores with apertures larger than $20 \mathrm{~nm}$ is stable. The incremental pore volume (IPV) and specific surface area (ISSA) of the XSY coal samples feature a bimodal pattern distribution, which is quite different from those for medium- and high-rank coal (Jian et al. 2015). The left peak of the IPV and ISSA is approximately $2 \mathrm{~nm}$, whereas that for the right peak ranges from 5-10 nm. With an increase in the pretreatment temperatures, the right peak gradually shifts to the right (Fig. 4). Furthermore, when the pretreatment temperature reaches to $300{ }^{\circ} \mathrm{C}$, the IPV and ISSA of the pores with apertures smaller than $5 \mathrm{~nm}$ cannot be detected with the $\mathrm{N}_{2}$ probe. This is primarily because of the irreversible shrinking of the pores during the loss of moisture under high pretreatment temperature (Deevi and Suuberg 1987).

\subsubsection{Change in mesopores and macropores in the coal}

The pores in the coal can be classified as micropores $(<2 \mathrm{~nm})$, mesopores $(2-50 \mathrm{~nm})$ and macropores $(>50 \mathrm{~nm})$ according to the recommended IUPAC pore classification method. With an increase in the pretreatment temperatures from 120 to $240{ }^{\circ} \mathrm{C}$, the mesopore volume and macropore volume of the XSY coal samples increase first and then decrease. When the pretreatment temperature reaches $270{ }^{\circ} \mathrm{C}$, there is a weak increase in the mesopore volume and macropore volume. In addition, the dynamic change in the mesopore volume and macropore volume is coincident. When the pretreatment temperature rises to $300{ }^{\circ} \mathrm{C}$, the mesopore volume decreases, whereas the macropore volume increases (Fig. 5). Previous studies on the pore structure of low-rank coal show that the mesopores are dominant (Nugroho et al. 2000; Mahidin et al. 2003; Cai et al. 2013), whereas the XSY coal samples demonstrate that the pore volumes are determined mainly by the macropores, and the mesopores account for most of the pore specific surface area (Fig. 5).

\subsection{Influence of various pretreatment temperatures on the change in the pore structure}

\subsubsection{Influence of pretreatment temperatures on sample mass}

The XSY coal samples feature high moisture and volatile content, which would be decomposed under high temperatures (Yin et al. 2019). With an increase in pretreatment temperatures, the mass of the XSY coal samples decreases continuously (Fig. 6). Particularly as the pretreatment temperature reaches $240{ }^{\circ} \mathrm{C}$, the mass of the coal sample rapidly decreases. The maximum decrease in the sample mass ranges from $2.27 \%$ to $2.73 \%$. The moisture and volatiles in the coal may decompose under high temperature, whereby a decrease in the coal sample mass may be related to a loss of moisture and volatiles under refined upgrading pretreatment temperatures. The water in the coal exists as interparticle water, capillary water, adhesion water, surface adsorption water and interior adsorption water (Le Roux and Campbell 2003; Peng et al. 2011; Daigle et al. 2014; Pickles et al. 2014). The XSY coal samples present low thermal maturity, in which the moisture content in the XSY coal samples is high (Table 1). Under a pretreatment temperature of $120^{\circ} \mathrm{C}$, which exceeds the boiling point of the water, the interparticle water in the coal would be evaporated first (Pickles et al. 2014). Higher temperatures would be needed to enable the loss of surface adsorption water and interior adsorption water in the coal; thus, decreasing the coal sample mass through the evaporation of adsorption water with higher pretreatment temperatures $\left(>120^{\circ} \mathrm{C}\right)$ would be difficult. However, the XSY coal samples contain high volatile content (Table 1). 

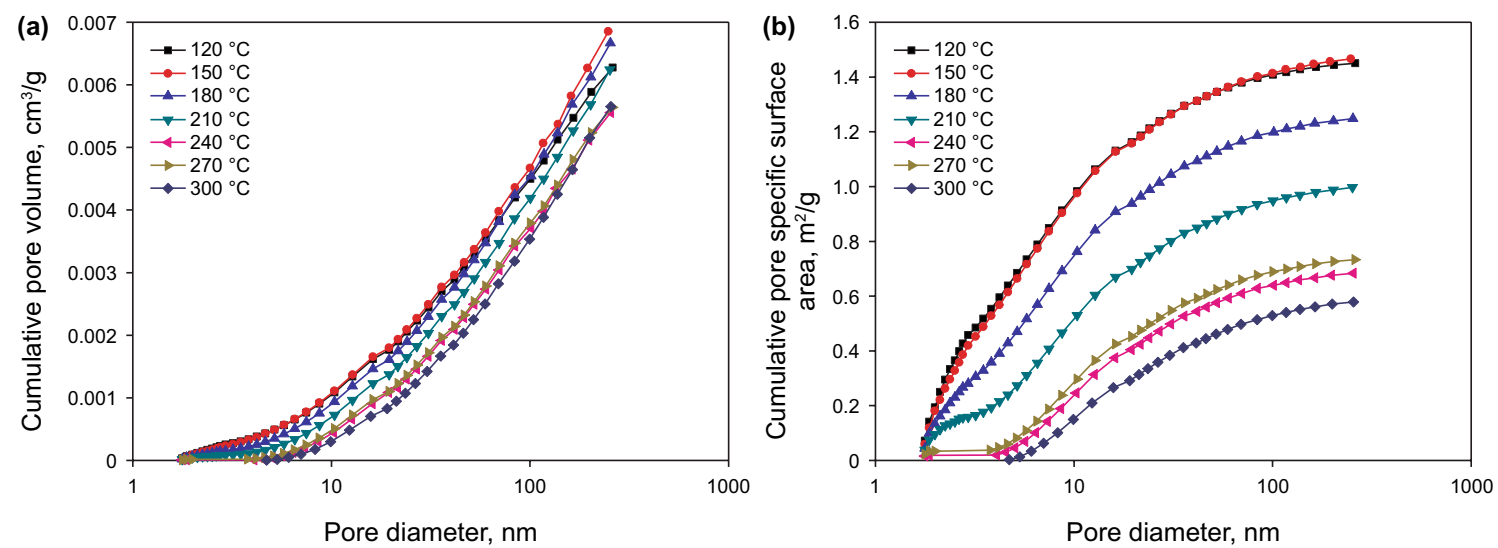

XSY-1 coal sample
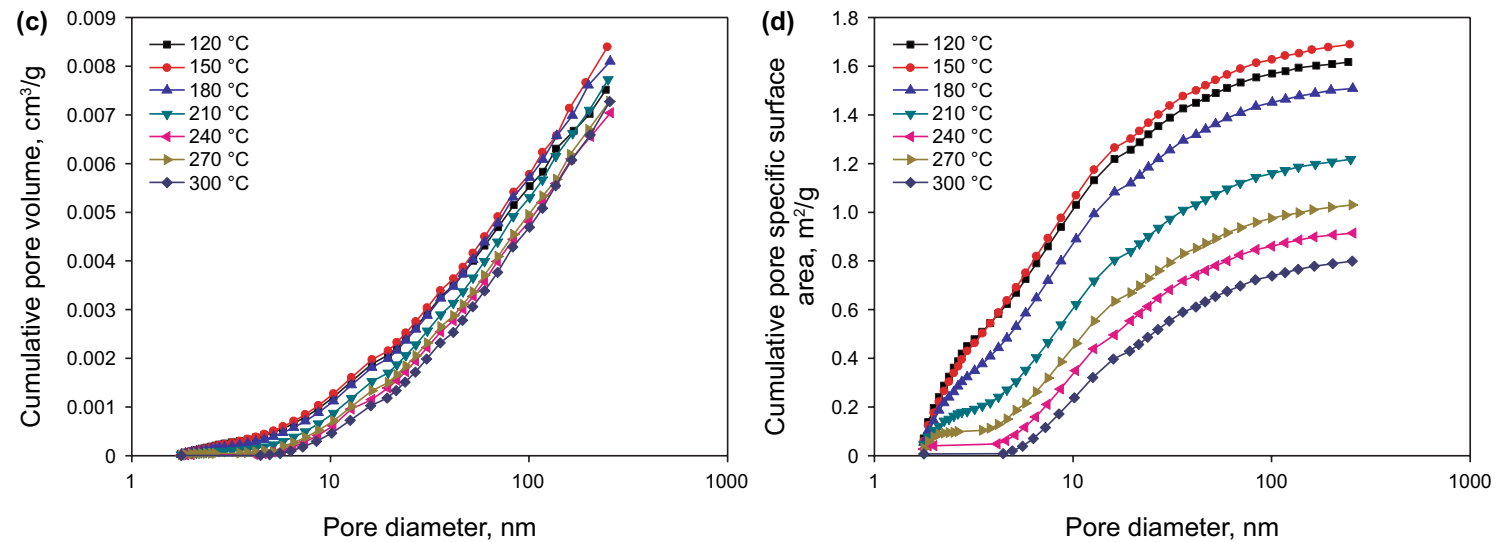

XSY-2 coal sample
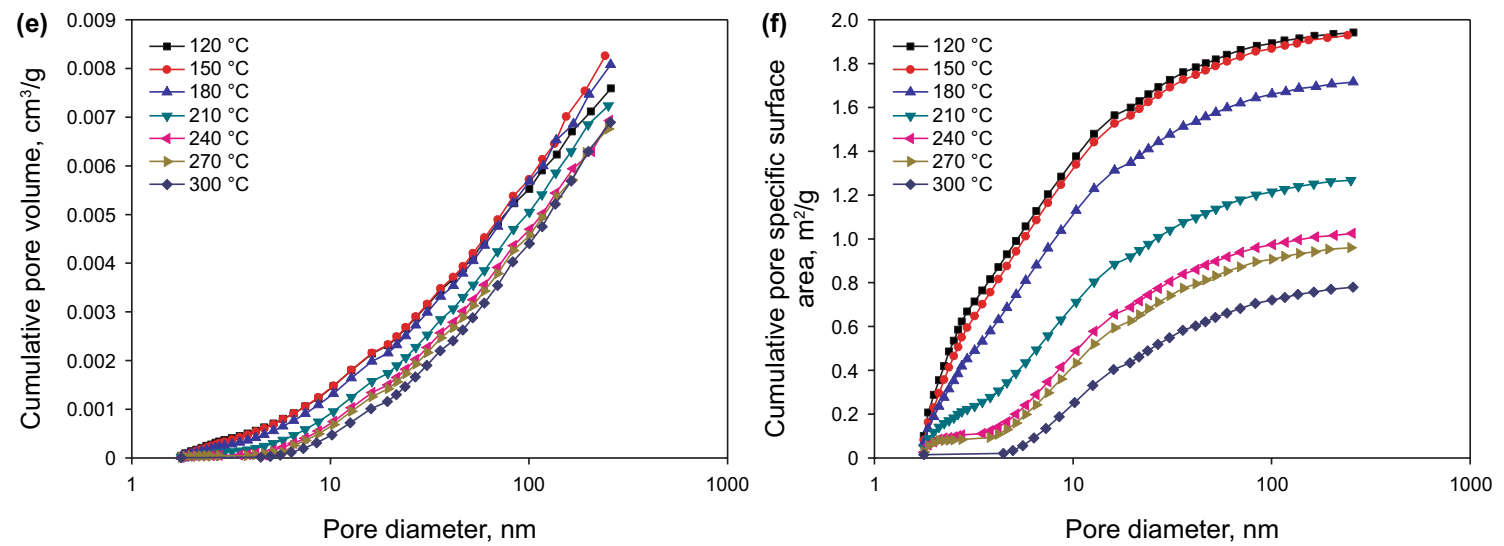

XSY-3 coal sample

Fig. $3 \mathrm{CPV}$ and CSSA of the three coal samples under various pretreatment temperatures

When the pretreatment temperature reaches $270{ }^{\circ} \mathrm{C}$, there is little pyrolysis oil that remains on the surface of the sample tube (Fig. 7). Owing to the high volatile content of the XSY coal samples, the volatiles would decompose to the pyrolysis gas under high temperatures; then, the pyrolysis gas would condense to pyrolysis oil upon the sufficient decrease in temperature. For an increase in the pretreatment temperature to $300{ }^{\circ} \mathrm{C}$, large quantities of pyrolysis oil can be found on the surface of the sample tube (Fig. 7). Then, the continuous decomposition of the volatile matter may contribute dominantly to the decrease in the coal sample mass. The evaporation of the moisture and decomposition of volatiles from the low-rank coal would lead to a change in the pore structure. 

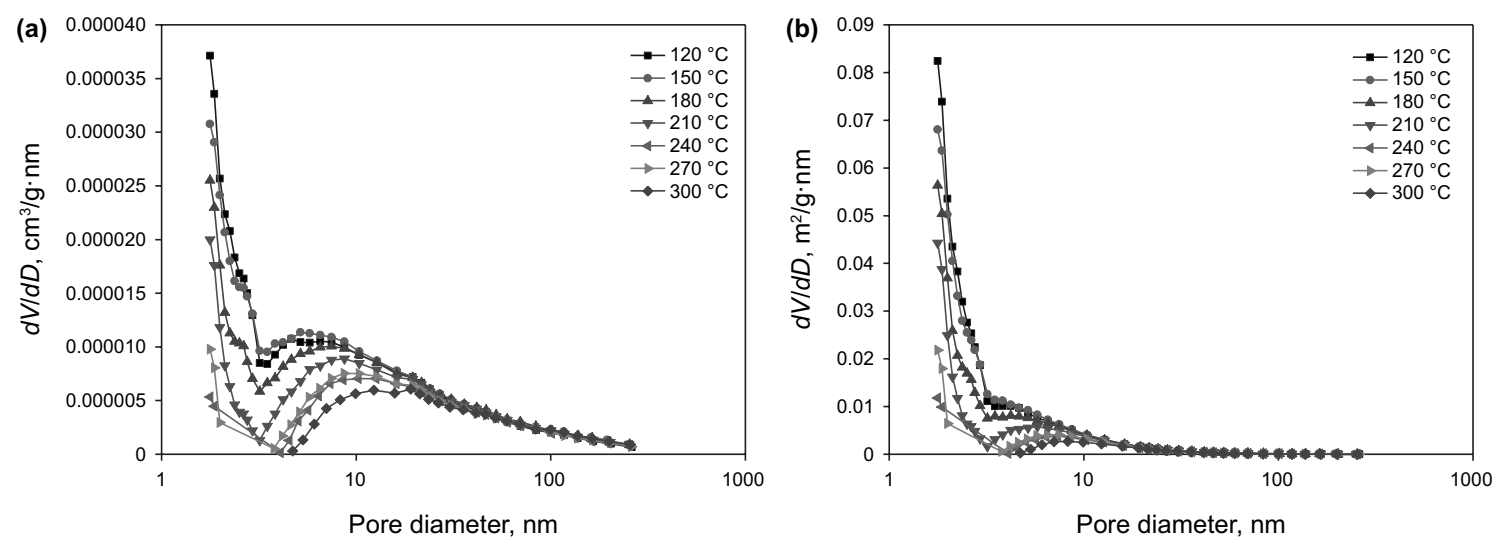

XSY-1 coal sample
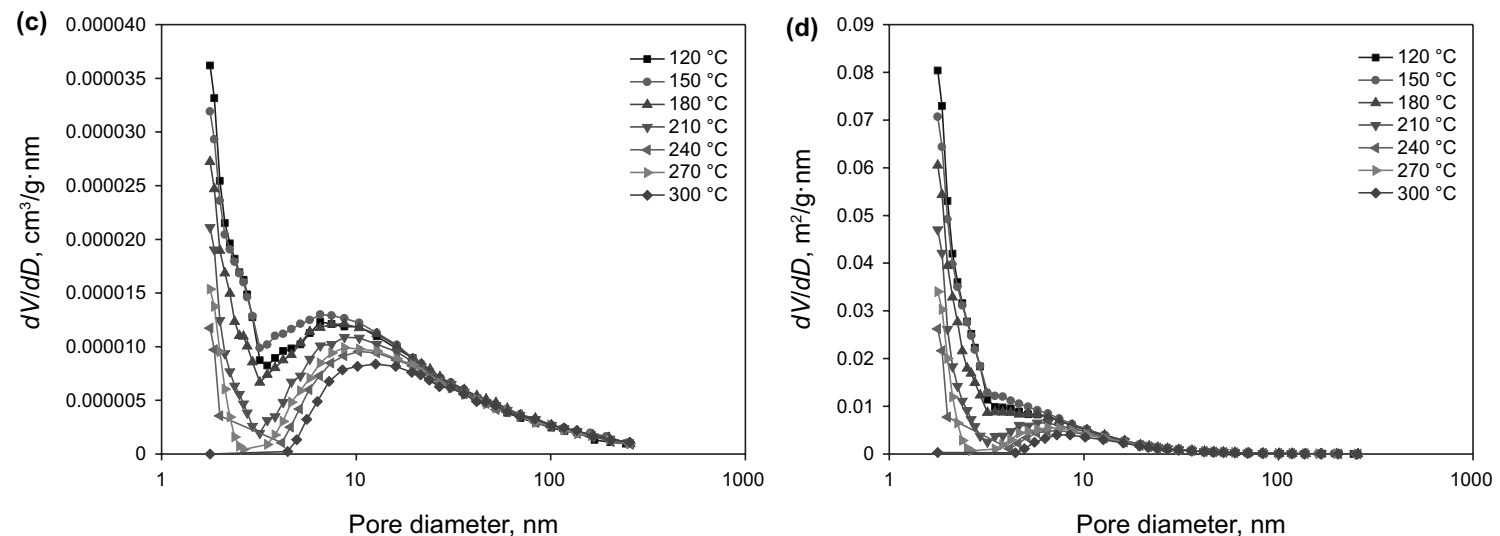

XSY-2 coal sample
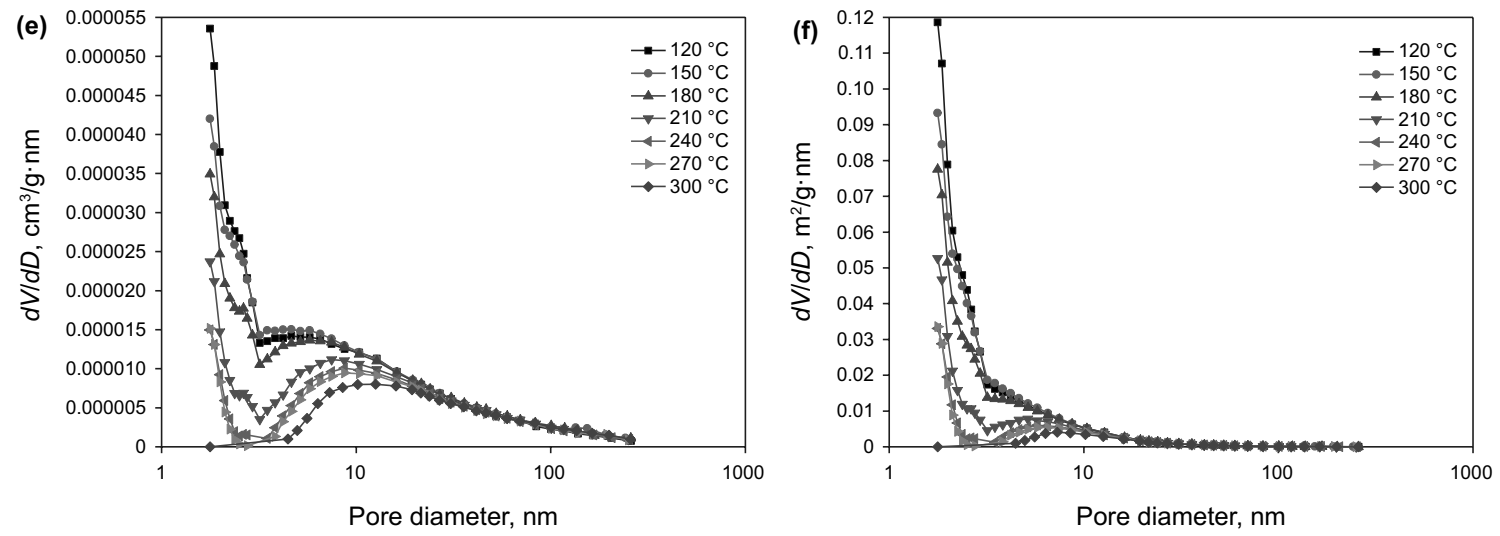

XSY-3 coal sample

Fig. 4 IPV and ISSA of the three coal samples under various pretreatment temperatures

\subsubsection{Influence of pretreatment temperatures on pore structure}

The thermal maturity of the XSY coal is low. Furthermore, the coal is loose and plant tissue pores and intergranular pores are the primary pores in the coal, with the former being is dominant. Figure 8 shows the plant tissue pores in the XSY coal samples without the inclusion of minerals. The plant tissue pores in the XSY coal samples are arranged directionally, in which parts of the plant tissue pores are compacted with an elliptical morphology. The pore aperture of the plant tissue pores is larger, ranging from 4.27 to $7.51 \mu \mathrm{m}$, and the maximum plant tissue pore diameter reaches $52.73 \mu \mathrm{m}$. The aperture of the intergranular pores is small. Besides the plant tissue pores and intergranular pores in the XSY coal samples, there are 

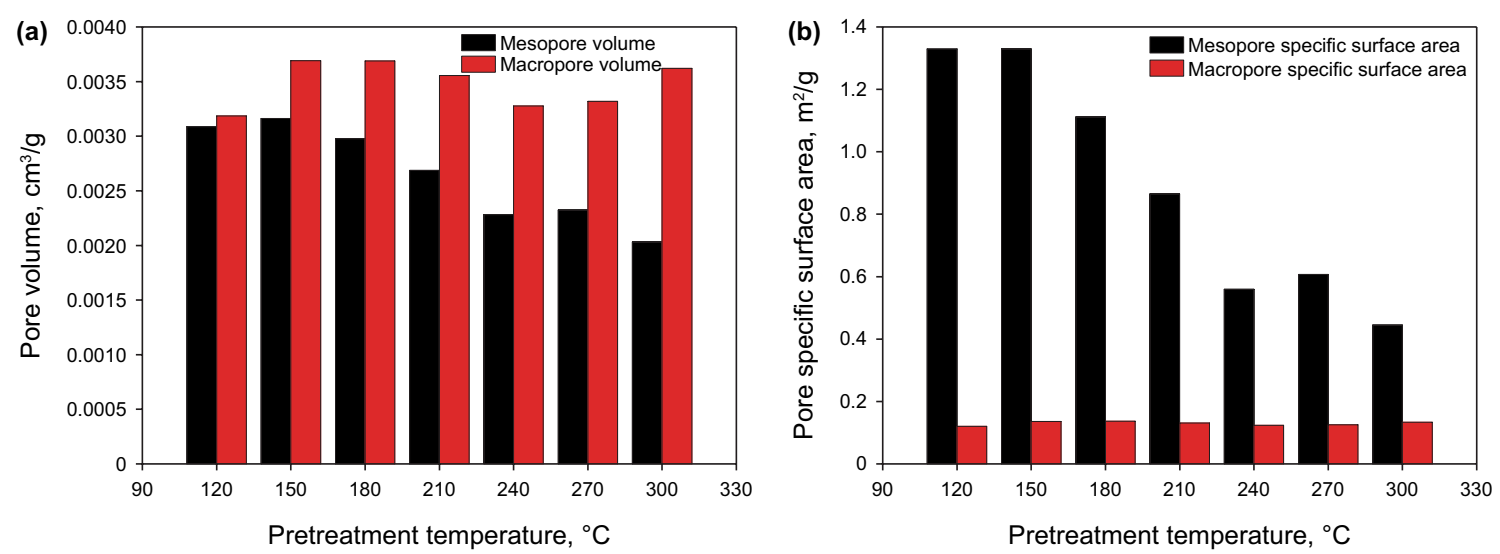

XSY-1 coal sample
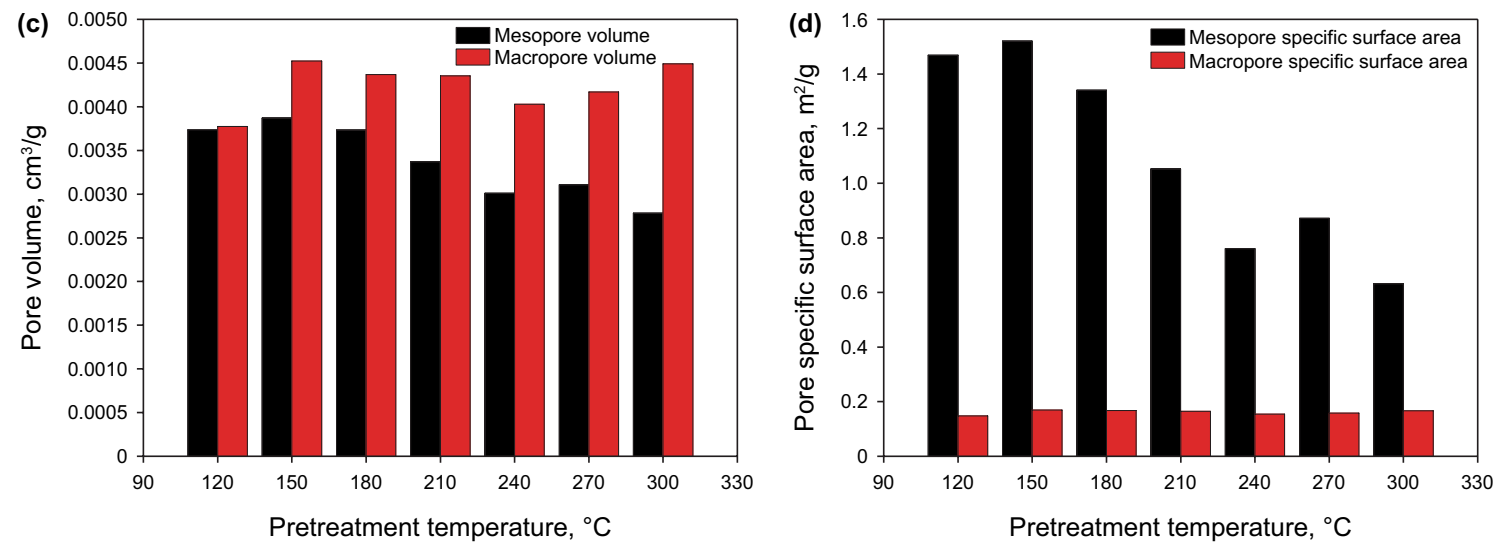

XSY-2 coal sample
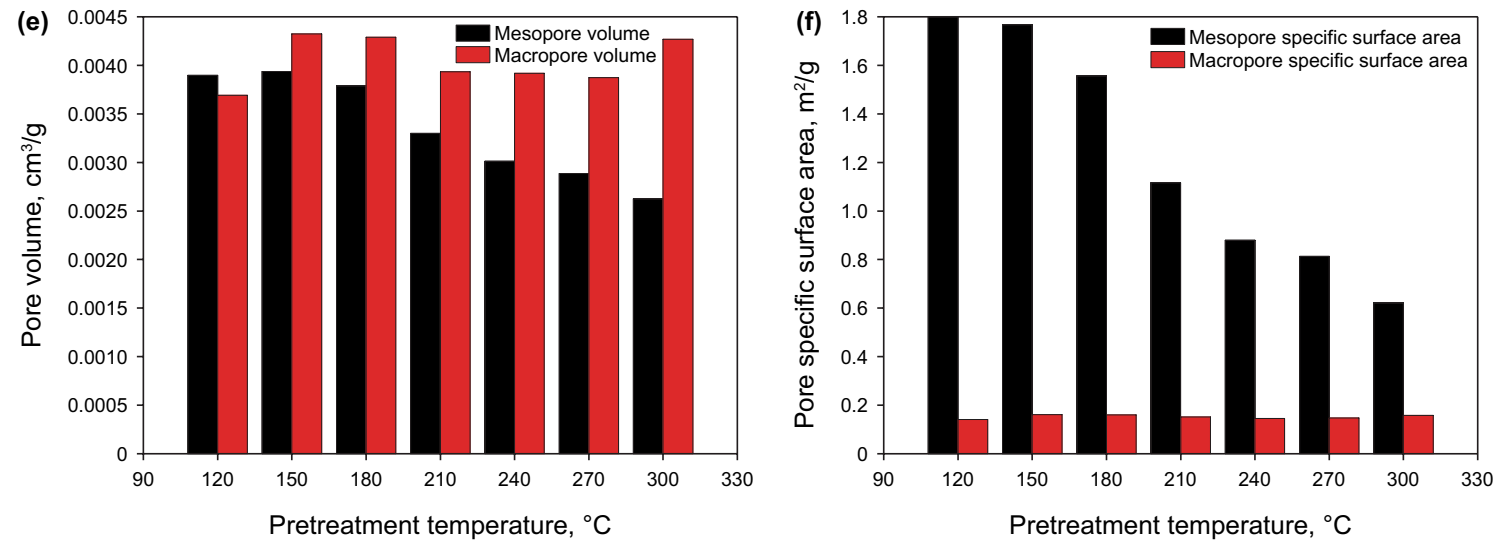

XSY-3 coal sample

Fig. $5 \mathrm{PV}$ and SSA of mesopore and macropore for the three coal samples under various pretreatment temperatures

also gas pores. The shape of the gas pores is solely elliptical, and almost all gas pores are filled with asphaltene (Fig. 8), with the fractures in the XSY coal samples serving as mainly water loss fractures. When the pretreatment temperatures exceed $270{ }^{\circ} \mathrm{C}$, the asphaltene decomposes, which increases the macropore volume.
The hysteresis loop of the same coal sample becomes narrower with an increase in the pretreatment temperatures (Fig. 1). The pores are mainly parallel plate pores for XSY coal samples, which favor the loss of moisture. When the pretreatment temperatures are improved, the water that exists in parts of the mesopores and micropores decomposes. The 


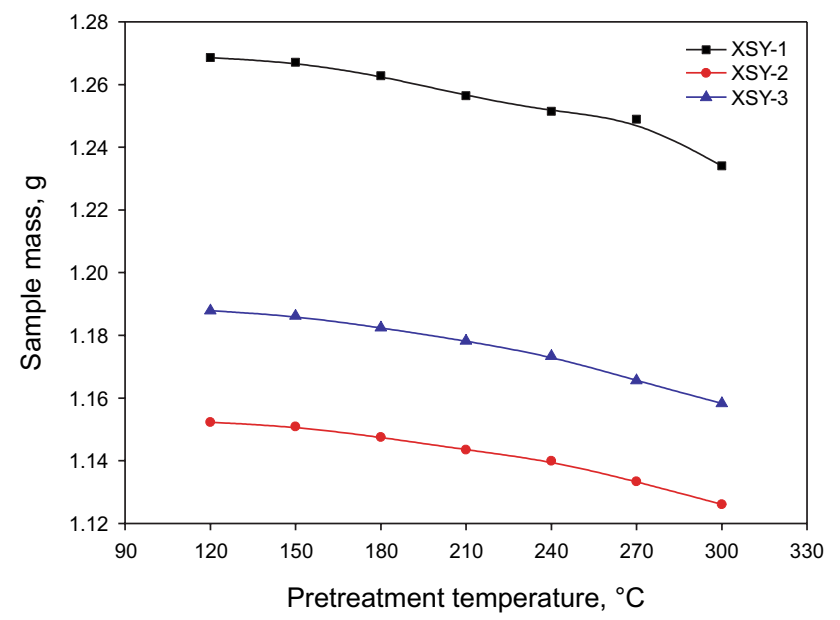

Fig. 6 Mass of XSY coal samples under various pretreatment temperatures

loss of moisture in the micropores leads to an increase in the pore aperture, which can finally enhance the pore connectivity of the coal. Under lower pretreatment temperatures, the hysteresis loop is larger, and fine-neck pores and ink-bottle pores are developed in the coals; however, these pores decrease with increased pretreatment temperatures. Furthermore, the dynamic change in the morphology is also controlled by the loss of volatiles in the coal. According to the SEM of the XSY coal samples, there is a certain amount of asphaltene in the XSY coal samples; the asphalteneis presented as scattered punctate on the surface of the coal matrix, with the asphaltene residing around the pores and fractures of the coal (Fig. 8). Wang et al. (1998) conducted the coal rock pyrolysis measurements with the low-rank coal sample from the Turpan-Hami Basin and reported that there would be a large amount of liquid hydrocarbon produced at the temperature of $240{ }^{\circ} \mathrm{C}$, with the liquid hydrocarbon adsorbed into the micropores of the coal. Although Jian et al. (2015) reported that there should not be a large amount of liquid hydrocarbon produced during the low coalification stage, the SEM results of the XSY coal samples demonstrate the contrary, supporting the views of Wang et al. (1998). With an increase in the pretreatment temperatures, the asphaltene and volatiles in the low-rank coal would be decomposed and discharged from the coal, altering the change in the pore structure. This would ultimately lead to a change in the LP- $\mathrm{N}_{2} \mathrm{~A}$ curves of the XSY coal sample with increased pretreatment temperatures.

\subsubsection{Influence of pretreatment temperatures on pore volume and specific surface area}

With a continuous decrease in the coal sample mass, the TPV of the coal samples demonstrates a three-step profile (Fig. 2). Under lower pretreatment temperatures, an increase in the TPV is related to the loss of the interparticle water in the macropores, which results in the shrinking of the coal matrix, and the shrinking and swelling of the low-rank coal response to later loss and uptake is quite common (Evans 1973; Deevi and Suuberg 1987; Suuberg et al. 1993; Kelemen et al. 2006; Fry et al. 2009). With further increase in the pretreatment temperature, the loss of the water would lead to the collapse of the pores in the coal (Evans 1973; Deevi and Suuberg 1987), contributing to the rapid decrease in TPV. When the low-rank coal samples were utilized with higher pretreatment temperatures, the asphaltene and volatiles in the low-rank coal
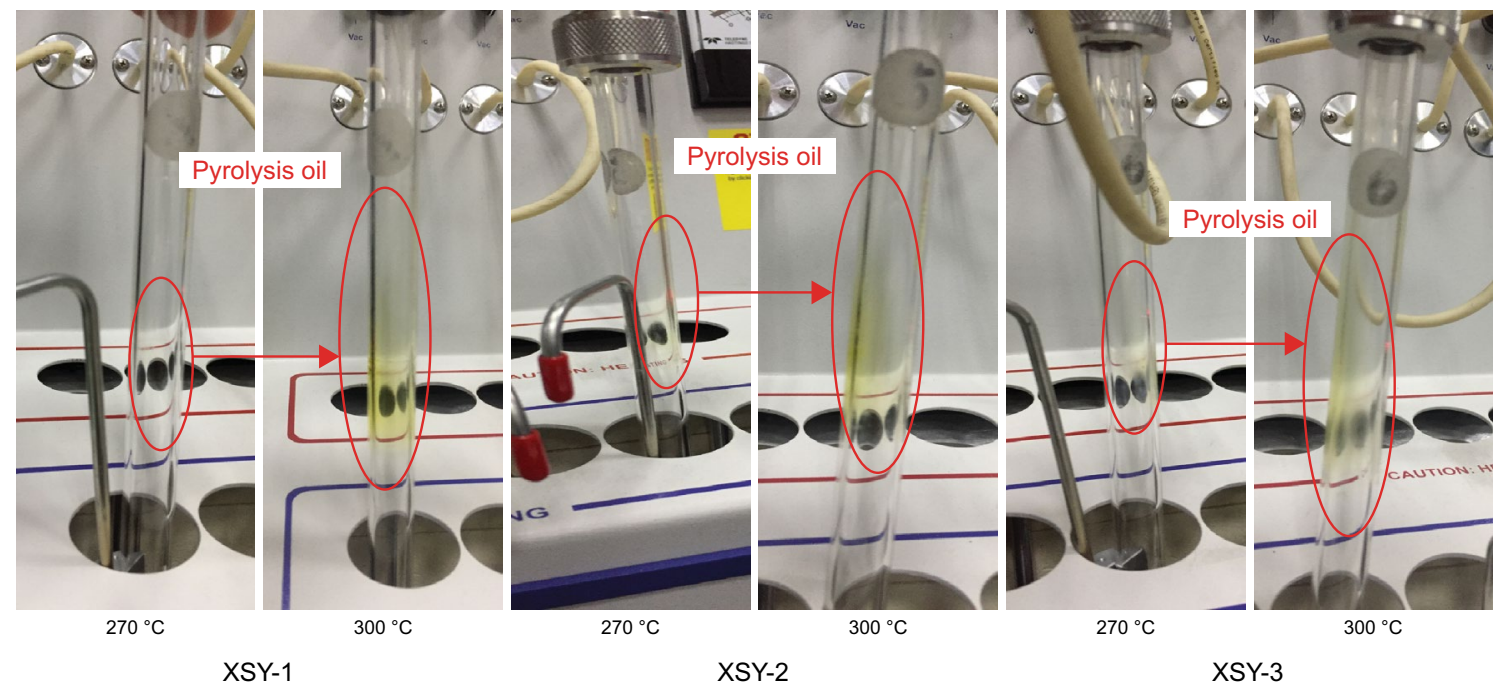

$\mathrm{XSY}-1$

XSY-2

XSY-3

Fig. 7 Condensates on the tube surfaces at the treatment temperatures of 270 and $300{ }^{\circ} \mathrm{C}$ for the three XSY coal samples 

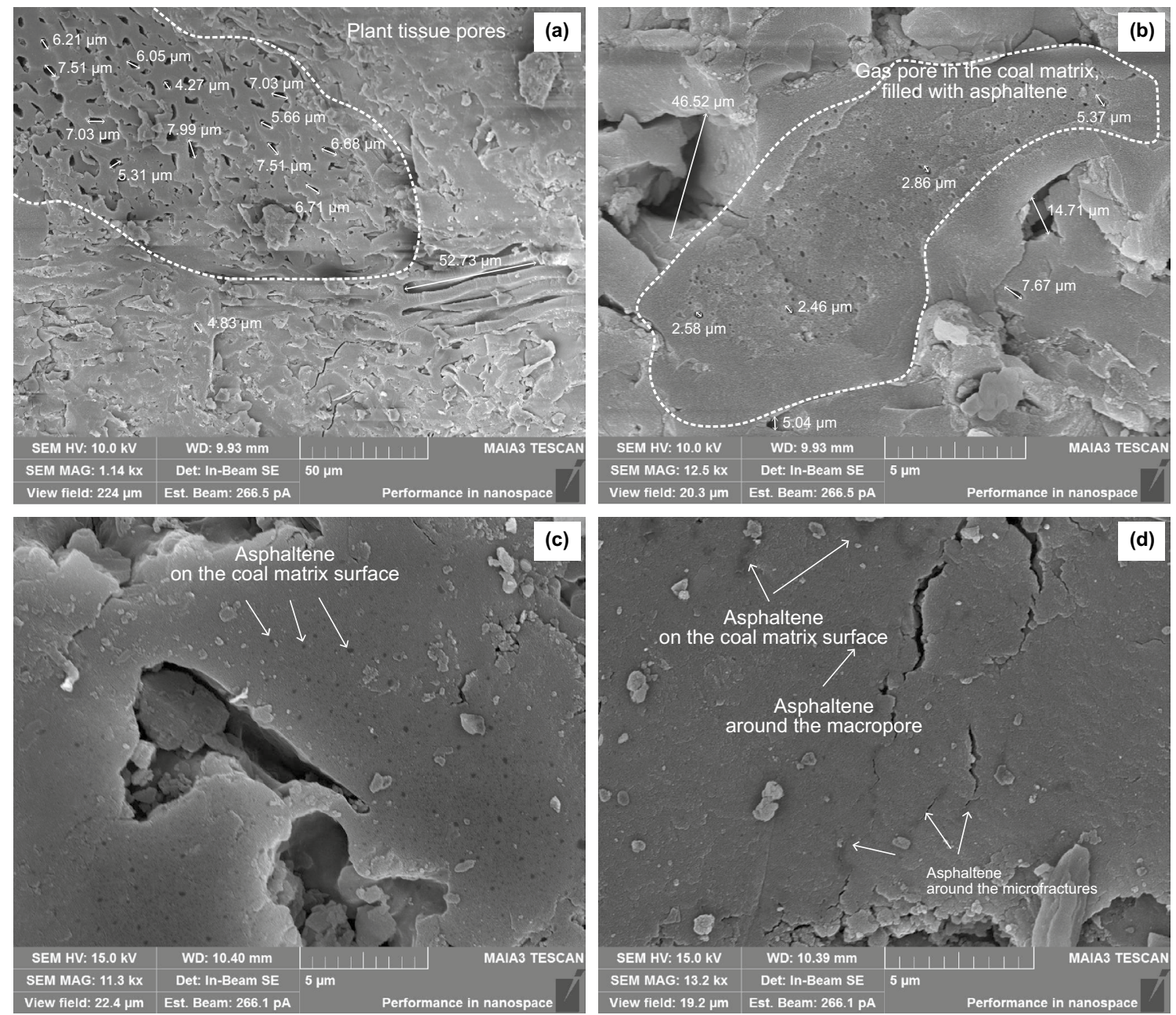

Fig. 8 SEM of pores in the XSY coal samples

were decomposed, which provided additional space in the coal, resulting in a weak increase in TPV (Fig. 8). Under higher pretreatment temperatures, with the quick evaporation of the moisture and decomposition of the volatiles, large amounts of pores would tend to collapse, and the TPV would further decrease; however, the TPV increases when the pretreatment temperatures exceed $240{ }^{\circ} \mathrm{C}$. This may be related to the ash in the coal (Yin et al. 2019); the ash would sustain the coal skeleton, promoting the stability of the PV. Furthermore, pore collapse mainly occurs for pores with apertures ranging from 2 to $18 \mathrm{~nm}$ (Deevi and Suuberg 1987), in which some of the mesopores collapse to the macropores, which ultimately leads to an increase in the TPV. As for the TSSA, owing to the pore collapse with increased pretreatment temperatures, the quantity of the micropores would decrease, leading to a continuous decrease in the TSSA.

\subsubsection{Influence of pretreatment temperatures on mesopores}

The PV and SSA of the XSY coal samples are mainly determined by pores with aperture smaller than $20 \mathrm{~nm}$, and these pores can be divided into those of 5 and $10 \mathrm{~nm}$ apertures. The mesopore volumes are mainly contributed by pores with aperture in the range of 10 to $20 \mathrm{~nm}$, followed by pores with apertures between 5 and $10 \mathrm{~nm}$, and finally, pores with apertures smaller than $5 \mathrm{~nm}$ (Fig. 9).

With an increase in the pretreatment temperatures, the $\mathrm{PV}$ of the pores with apertures smaller than $5 \mathrm{~nm}$ decreases, which is due to the collapse of the pores in the XSY coal samples. When the pretreatment temperature reaches to $300{ }^{\circ} \mathrm{C}$, the pore volume contributed by pores with apertures smaller than $5 \mathrm{~nm}$ almost disappears. Although the pore volume of the pores with apertures below $5 \mathrm{~nm}$ is smallest, this pore category is responsible for most of the pore specific 

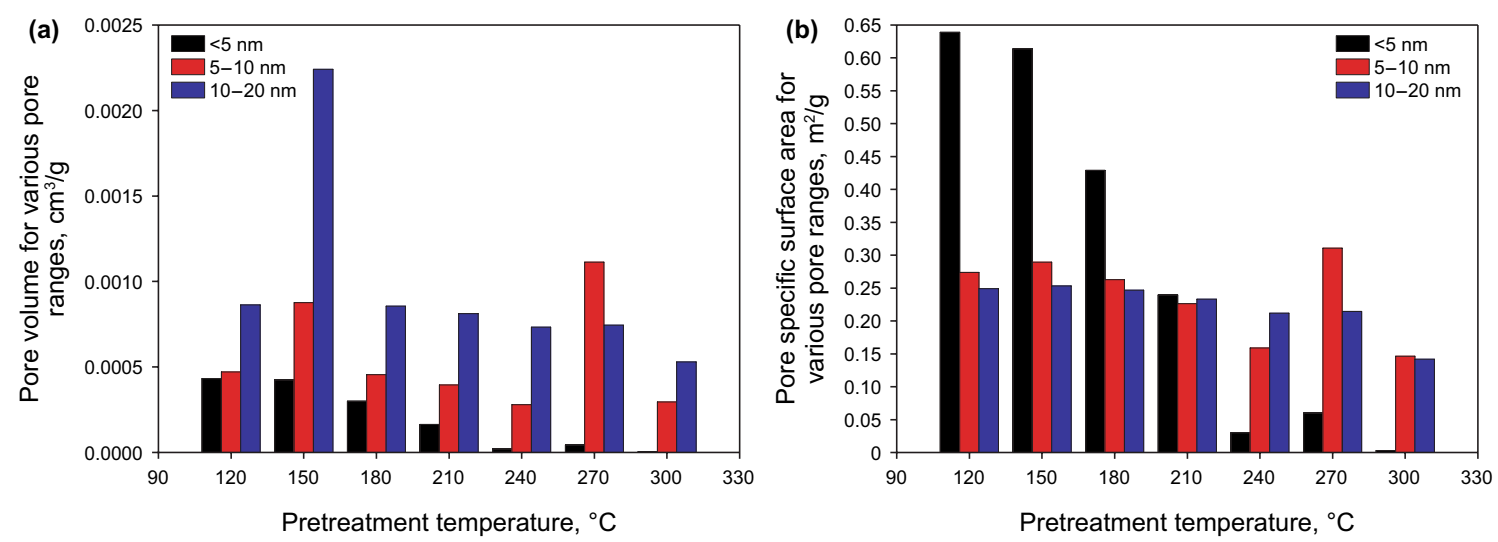

XSY-1 coal sample
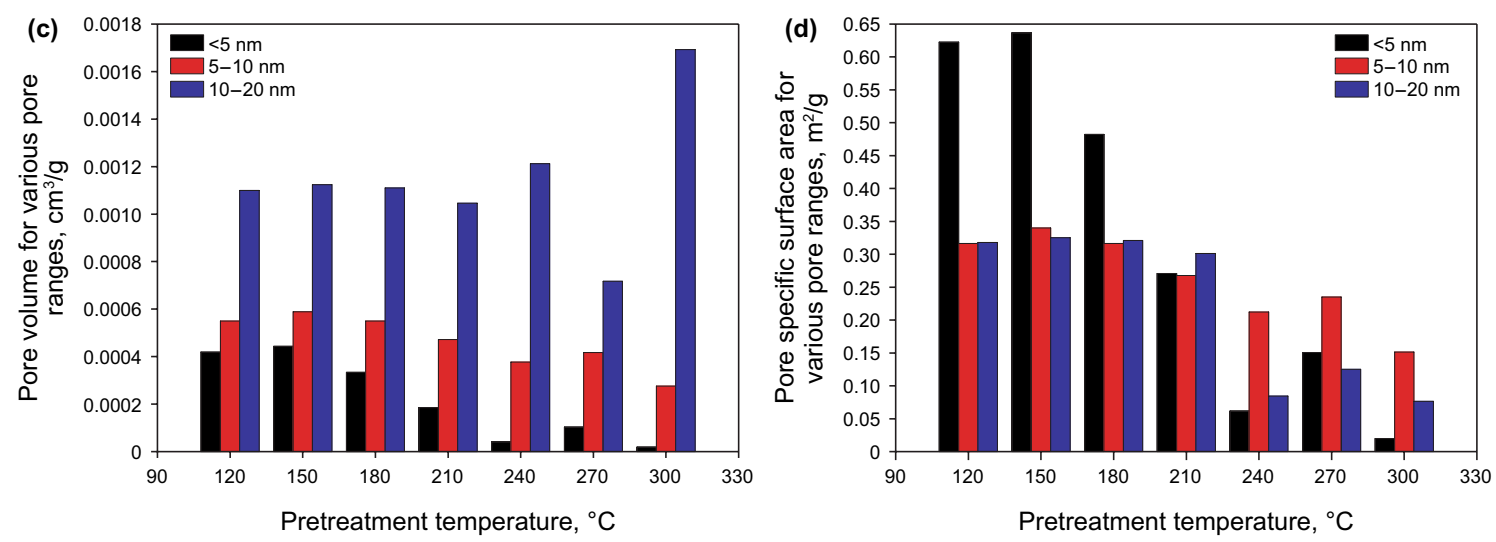

XSY-2 coal sample
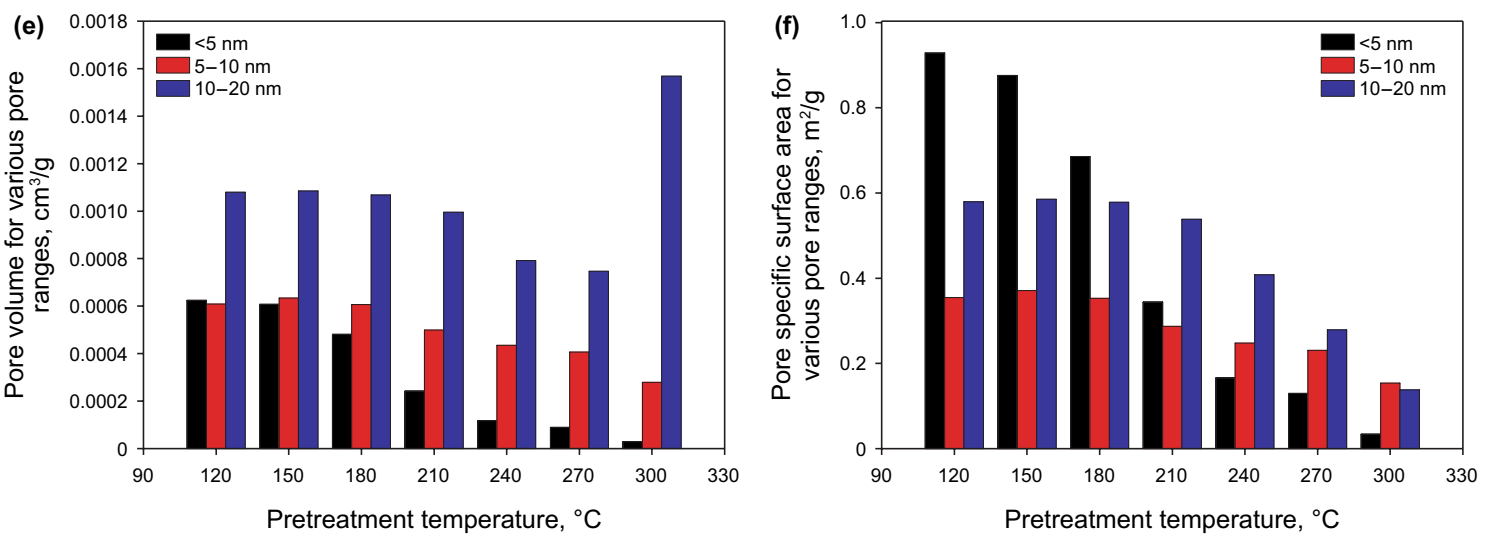

XSY-3 coal sample

Fig. 9 PV and SSA with various pore ranges of mesopores for the three coal samples under various pretreatment temperatures

surface area at low pretreatment temperatures, whereby it decreases with increased pretreatment temperatures. The dynamic change characteristics of pores with apertures of $5-10 \mathrm{~nm}$ is similar to those for pores with pore apertures smaller than $5 \mathrm{~nm}$, whereby the decrease in the pore volume and pore specific surface area is weak. In terms of pores with the apertures of 10-20 nm, the dynamic change in the pore volume and pore specific surface area is much more complicated, indicating the complexity and heterogeneity of the pores. When the pretreatment temperature reaches $300{ }^{\circ} \mathrm{C}$, there is a sharp increase in the pore volume for pores with apertures of $10-20 \mathrm{~nm}$, whereas the pore specific surface area decreases continuously until it reaches the minimum at the pretreatment temperature of $300{ }^{\circ} \mathrm{C}$ (Fig. 9).

The dynamic change in mesopores with an aperture of 2-20 $\mathrm{nm}$ can be determined with the XSY coal samples in 
this study. With an increase in the pretreatment temperatures, the contribution of mesopores volume is mainly provided by pores with apertures of $10-20 \mathrm{~nm}$, and that for pores with the apertures of $2-5 \mathrm{~nm}$ decreases continuously. The mesopores with pore apertures of 5-10 $\mathrm{nm}$ are regarded as an intermediate between the two extremes. The contribution to pore specific surface area changes significantly with an increase in pretreatment temperatures. The pore specific surface area is accounted for mainly by mesopores with apertures smaller than $5 \mathrm{~nm}$, whereas 5-10 nm mesopores are primarily responsible under high pretreatment temperatures. It is known that the pores with apertures below $10 \mathrm{~nm}$ are dominantly adsorption pores, the continuous decreases of these pores $(<10 \mathrm{~nm})$ will decrease the adsorption capacities of the low-rank coal, leading to the decrease of the adsorbed quantity (Fig. 1). However, it should not be ignored that the pore volumes of the pores with the apertures greater than $10 \mathrm{~nm}$ feature stable or a faint decrease, and the hysteresis loops also decreased with the increased pretreatment temperatures (Fig. 1), indicating the enhanced pore connectivity, which will promote the migration of the methane in low-rank coal.

\section{Conclusions}

(1) The pore structure characteristics of low-rank coal feature a significant heating effect. With increased pretreatment temperatures, the total pore volumes of the XSY coal samples exhibits as three-step profile, which involves the continuous loss of water and volatiles in the low-rank coal. Under lower pretreatment temperatures $\left(\leq 150^{\circ} \mathrm{C}\right)$, the loss of moisture from the meso- and macropores results in an increase in the pore volume. With further increase in the pretreatment temperature, the pore collapse produced by the massive decomposition of the volatiles leads to a decrease in the pore volume. However, the coal skeleton remains stable under high pretreatment temperatures $\left(>240{ }^{\circ} \mathrm{C}\right)$ owing to the ash in the coal; consequently, the decomposition of the volatiles serves to increase the pore volume.

(2) The influence of the heating effect on pore structure mainly occurs on the pores with apertures smaller than $20 \mathrm{~nm}$. When the pretreatment temperature is lower than $150{ }^{\circ} \mathrm{C}$, pores with an aperture smaller than $5 \mathrm{~nm}$ collapse dominantly. As for the mesopores with aperture ranges from 5 to $10 \mathrm{~nm}$, these pores can also collapse under higher pretreatment temperatures $\left(150-270{ }^{\circ} \mathrm{C}\right)$. When the pretreatment temperature reaches $300{ }^{\circ} \mathrm{C}$, the mesopores with apertures smaller than $5 \mathrm{~nm}$ almost disappear, and the pore volume of the mesopores with apertures larger than $10 \mathrm{~nm}$ increases significantly.
Acknowledgements The authors thank a lot for the help of Master $\mathrm{Li}$-Rong Gao on the measurements of the $\mathrm{LP}-\mathrm{N}_{2} \mathrm{~A}$ on the coal samples.

Funding This work was supported by the Natural Science Basic Research Plan in Shaanxi Province of China (Program No. 2019JQ527), Shandong Key laboratory of Depositional Mineralization and Sedimentary Mineral Open Fund (Program No. DMSM20190014) and Scientific Research Program Funded by Shaanxi Provincial Education Department (Program No. 20JS116).

\section{Compliance with ethical standards}

Conflict of interest The author(s) declared no potential conflicts of interest with respect to the research, authorship, and/or publication of this article.

Open Access This article is licensed under a Creative Commons Attribution 4.0 International License, which permits use, sharing, adaptation, distribution and reproduction in any medium or format, as long as you give appropriate credit to the original author(s) and the source, provide a link to the Creative Commons licence, and indicate if changes were made. The images or other third party material in this article are included in the article's Creative Commons licence, unless indicated otherwise in a credit line to the material. If material is not included in the article's Creative Commons licence and your intended use is not permitted by statutory regulation or exceeds the permitted use, you will need to obtain permission directly from the copyright holder. To view a copy of this licence, visit http://creativecommons.org/licenses/by/4.0/.

\section{References}

Burgess CGV, Everett DH, Nuttall S. Adsorption hysteresis in porous materials. Pure Appl Chem. 1989;61(11):1845-52. https://doi. org/10.1351/pac198961111845.

Cai YD, Liu DM, Pan ZJ, et al. Pore structure and its impact on $\mathrm{CH}_{4}$ adsorption capacity and flow capability of bituminous and subbituminous coals from Northeast China. Fuel. 2013;103:258-68. https://doi.org/10.1016/j.fuel.2012.06.055.

Chen YL, Qin Y, Wei CT, et al. Porosity changes in progressively pulverized anthracite subsamples: implications for the study of closed pore distribution in coals. Fuel. 2018;225:612-22. https:// doi.org/10.1016/j.fuel.2018.03.164.

Daigle H, Johnson A, Thomas B. Determining fractal dimension from nuclear magnetic resonance data in rocks with internal magnetic field gradients. Geophysics. 2014;79(6):D425-31. https://doi. org/10.1190/GEO2014-0325.1.

Deevi SC, Suuberg EM. Physical changes accompanying drying of western US lignites. Fuel. 1987;66(4):454-60. https://doi. org/10.1016/0016-2361(87)90147-5.

Evans DG. The brown-coal/water system: Part 4. Shrinkage on drying. Fuel. 1973;52(3):186-90. https://doi.org/10.1016/00162361(73)90077-X.

Fry R, Day S, Sakurovs R. Moisture-induced swelling of coal. Int J Coal Prep Util. 2009;29(6):298-316. https://doi.org/10.1080/19392 690903584575.

Fu HJ, Tang DZ, Xu H, et al. Geological characteristics and CBM exploration potential evaluation: a case study in the middle of the southern Junggar Basin, NW China. J Nat Gas Sci Eng. 2016;30:557-70. https://doi.org/10.1016/j.jngse.2016.02.024.

Fu HJ, Tang DZ, Xu T, et al. Characteristics of pore structure and fractal dimension of low-rank coal: a case study of Lower Jurassic 
Xishanyao coal in the southern Junggar Basin. NW China Fuel. 2017;193:254-64. https://doi.org/10.1016/j.fuel.2016.11.069.

Groen JC, Peffer LA, Pérez-Ramı́rez J. Pore size determination in modified micro- and mesoporous materials. Pitfalls and limitations in gas adsorption data analysis. Micropor Mesopor Mat. 2003;60(13):1-17. https://doi.org/10.1016/S1387-1811(03)00339-1.

Jian K, Fu XH, Ding YM, et al. Characteristics of pores and methane adsorption of low-rank coal in China. J Nat Gas Sci Eng. 2015;27(Part 1): 207-18. doi: https://doi.org/10.1016/j.jngse .2015.08.052.

Kelemen SR, Kwiatek LM, Siskin M, et al. Structural response of coal todrying and pentane sorption. Energy Fuel. 2006;20(1):205-13. https://doi.org/10.1021/ef0580218.

Le Roux M, Campbell QP. An investigation into an improved method of fine coal dewatering. Min Eng. 2003;16(10):999-1003. https ://doi.org/10.1016/j.mineng.2003.08.004.

Lee GJ, Pyun SI, Rhee CK. Characterization of geometric and structural properties of pore surfaces of reactivated microporous carbons based upon image analysis and gas adsorption. Micropor Mesopor Mat. 2006;93(1-3): 217-25. doi: https://doi. org/10.1016/j.micromeso.2006.02.025.

Li X, Fu XH, Yang XS, et al. Coalbed methane accumulation and dissipation patterns: a case study of the Junggar Basin, NW China. J Asian Earth Sci. 2018;160:13-26. https://doi.org/10.1016/j.jseae s.2018.04.003.

Li FL, Jiang B, Cheng GX, et al. Structural and evolutionary characteristics of pore-microfractures and their influence on coalbed methane exploitation in high-rank brittle tectonically deformed coals of the Yangquan mining area, northeastern Qinshui basin. J Petrol Sci Eng. 2019;174:1290-302. https://doi.org/10.1016/j. petrol.2018.11.081.

Liu HH, Mou JH, Cheng YP. Impact of pore structure on gas adsorption and diffusion dynamics for long-flame coal. J Nat Gas Sci Eng. 2015;22:203-13. https://doi.org/10.1016/j.jngse.2014.11.030.

Mahidin, Ogaki Y, Usui H, et al. The advantages of vacuum-treatment in the thermal upgrading of low-rank coals on the improvement of dewatering and devolatilization. Fuel Process Technol. 2003;84(1-3): 147-60. doi: https://doi.org/10.1016/S0378 $-3820(03) 00052-3$.

Nugroho YS, Mclntosh AC, Gibbs BM. Low-temperature oxidation of single and blended coals. Fuel. 2000;79(15):1951-61. https://doi. org/10.1016/S0016-2361(00)00053-3.

Pan JN, Zhang ZZ, Li M, et al. Characteristics of multi-scale pore structure of coal and its influence on permeability. Nat Gas Ind B. 2019;6(4):357-65. https://doi.org/10.1016/j.ngib.2019.01.012.

Peng ZW, Hwang JY, Mouris J, et al. Microwave absorption characteristics of conventionally heated nonstoichiometric ferrous oxide. Metall Mater Trans A. 2011;42:2259-63. https://doi.org/10.1007/ s11661-011-0652-9.

Pickles CA, Gao F, Kelebek S. Microwave drying of a low-rank sub-bituminous coal. Min Eng. 2014;62:31-42. https://doi. org/10.1016/j.mineng.2013.10.011.

Sakurovs R, He LL, Melnichenko YB, et al. Pore size distribution and accessible pore size distribution in bituminous coals. Int J Coal Geol. 2012;100:51-64. https://doi.org/10.1016/j. coal.2012.06.005.

Sakurovs R, Lewis C, Wibberley L. Effect of heat and moisture on surface titratability and pore size distribution of Victorian brown coals. Fuel. 2016;172:124-9. https://doi.org/10.1016/j. fuel.2016.01.004

Salmas CE, Tsetsekou AH, Hatzilyberis KS, et al. Evolution lignite mesopore structure during drying. Effect of temperature and heating time. Dry Technol. 2001;19(1):35-64. https://doi.org/10.1081/ DRT-100001351.

Sing KSW, Everett DH, Haul RAW, et al. Reporting physisorption data for gas/solid systems with special reference to the determination of surface area and porosity (Recommendations 1984). Pure Appl Chem. 1985;57:603-19. https://doi.org/10.1515/iupac.57.0007.

Song Y, Jiang B, Liu JG. Nanopore structural characteristics and their impact on methane adsorption and diffusion in low to medium tectonically deformed coals: case study in the Huaibei coal field. Energy Fuel. 2017;31(7):6711-23. https://doi.org/10.1021/acs. energyfuels.7b00512.

Suuberg EM, Otake Y, Yun Y, et al. Role of moisture in coal structure and the effects of drying upon the accessibility of coal structure. Energy Fuel. 1993;7(3):384-92. https://doi.org/10.1021/ef000 $39 \mathrm{a} 009$.

Tao S, Chen SD, Tang DZ, et al. Material composition, pore structure and adsorption capacity of low-rank coals around the first coalification jump: a case study of eastern Junggar Basin. China Fuel. 2018;211:804-15. https://doi.org/10.1016/j.fuel.2017.09.087.

Thommes M, Cychosz KA. Physical adsorption characterization of nanoporous materials: progress and challenges. Adsorption. 2014;20:233-50. https://doi.org/10.1007/s10450-014-9606-z.

Wang CJ, Fu JM, Sheng GY, et al. Laboratory thermal simulation of liquid hydrocarbon generation and evolution of Jurassic coals from the Turpan-Hami Basin. Acta Geol Sin. 1998;72(3):276-84.

Wang BY, Qin Y, Shen J, et al. Summarization of geological study on low rank coalbed methane in China. Coal Sci Technol. 2017;45(1):170-9. https://doi.org/10.13199/j.cnki.cst.2017.01.028 (In Chinese).

Wang BY, Qin Y, Shen J, et al. Pore structure characteristics of lowand medium-rank coals and their differential adsorption and desorption effects. J Petrol Sci Eng. 2018;165:1-12. https://doi. org/10.1016/j.petrol.2018.02.014.

Xin FD, Xu H, Tang DZ, et al. Pore structure evolution of low-rank coal in China. Int J Coal Geol. 2019;205:126-39. https://doi. org/10.1016/j.coal.2019.02.013.

Xu H, Tang DZ, Liu DM, et al. Study on coalbed methane accumulation characteristics and favorable areas in the Binchang area, southwestern Ordos Basin, China. Int J Coal Geol. 2012;95:1-11. https://doi.org/10.1016/j.coal.2012.02.001.

Yin ZY, Xu H, Tang DZ, et al. Study on pore structure change during different coal grade pyrolysis. Coal Sci Technol. 2019;47(9):74-9. https://doi.org/10.13199/j.cnki.cst.2019.09.006 (In Chinese).

Zhang M, Fu XH, Wang HD. Analysis of physical properties and influencing factors of middle-rank coal reservoirs in China. J Nat Gas Sci Eng. 2018;50:351-63. https://doi.org/10.1016/j.jngse .2017.12.018.

Zhao JL, Tang DZ, Qin Y, et al. Fractal characterization of pore structure for coal macrolithotypes in the Hancheng area, southern Ordos Basin, China. J Petrol Sci Eng. 2019;178:666-77. https:// doi.org/10.1016/j.petrol.2019.02.060. 